\title{
EFFECTS OF VARIOUS TREATMENTS WITH 6-METHYL-17-ACETOXYPROGESTERONE (MAP) ON SUBSEQUENT FERTILITY IN EWES
}

\author{
C. V. HULET \\ U.S. Department of Agriculture, U.S. Sheep Experiment Station, ARS, Dubois, Idaho
}

(Received 26th July 1965)

\begin{abstract}
Summary. A higher proportion of ewes lambed to the first service $(P<0.01)$ when put to the ram at the second heat after treatment with MAP $(123 / 162,75.9 \%)$ than when mated at the first heat after treatment $(89 / 158,56 \cdot 3 \%)$. A $60 \mathrm{mg}$ daily dosage of MAP resulted in $13 \%$ more ewes lambing to the first service than did a $50 \mathrm{mg}$ dosage rate $(73.1 \%$ versus $59.8 \%, P>0.05)$. There was no significant difference in fertility subsequent to MAP treatment for 12 versus 14 days.
\end{abstract}

Much interest has been shown in synchronizing oestrus in sheep with oral progestagens. However, initial fertility of synchronized ewes is generally below that of untreated animals (Davies, 1960; Brunner, Hansel \& Hogue, 1964). Several studies, including Hogue, Hansel \& Bratton (1962) and Brunner et al. (1964), have shown that ewes which fail to settle at the first heat after treatment may have a higher non-return rate at the second heat after treatment than did all ewes mated at the first heat. Foote \& Waite (1965) found reduced fertility at the first heat after treatment following synchronization with crystalline progesterone. However, it appears that no direct comparisons of fertility at first versus second heats after treatment oestrus have been made using oral progestagens.

The purpose of this study was to compare fertility and synchronization of lambing in MAP-treated ewes mated at the first heat after treatment, with the results in similarly treated ewes mated contemporaneously at the second heat after treatment. In what follows the first, second or third heat means the first, second, or third heat after treatment. The effects on fertility and lambing synchrony of 50 versus $60 \mathrm{mg}$ of MAP and 12 versus 14 days of administration with either of these levels of MAP were also studied. A $2 \times 2 \times 2$ factorial design was used. In 1962 and 1963 ewes of Rambouillet, Targhee and Columbia breeding were assigned at random within age, breed and rams with which mated, to eight treatment groups. The ewes were group fed MAP in $340 \mathrm{~g}$ of alfalfa pellets/ head/day. Those ewes given MAP for 14 days were started on treatment 2 days earlier than those given MAP for 12 days. Those first exposed to the rams at the second heat were started on treatment 16 days earlier than those first exposed 283 
at the first heat. Thus, ewes from each of the treatment groups exhibited heat and were mated at approximately the same time.

Although oestrus was checked using sterilized rams, only lambing data as enumerated below are reported in this paper: (1) Percentage of ewes lambing
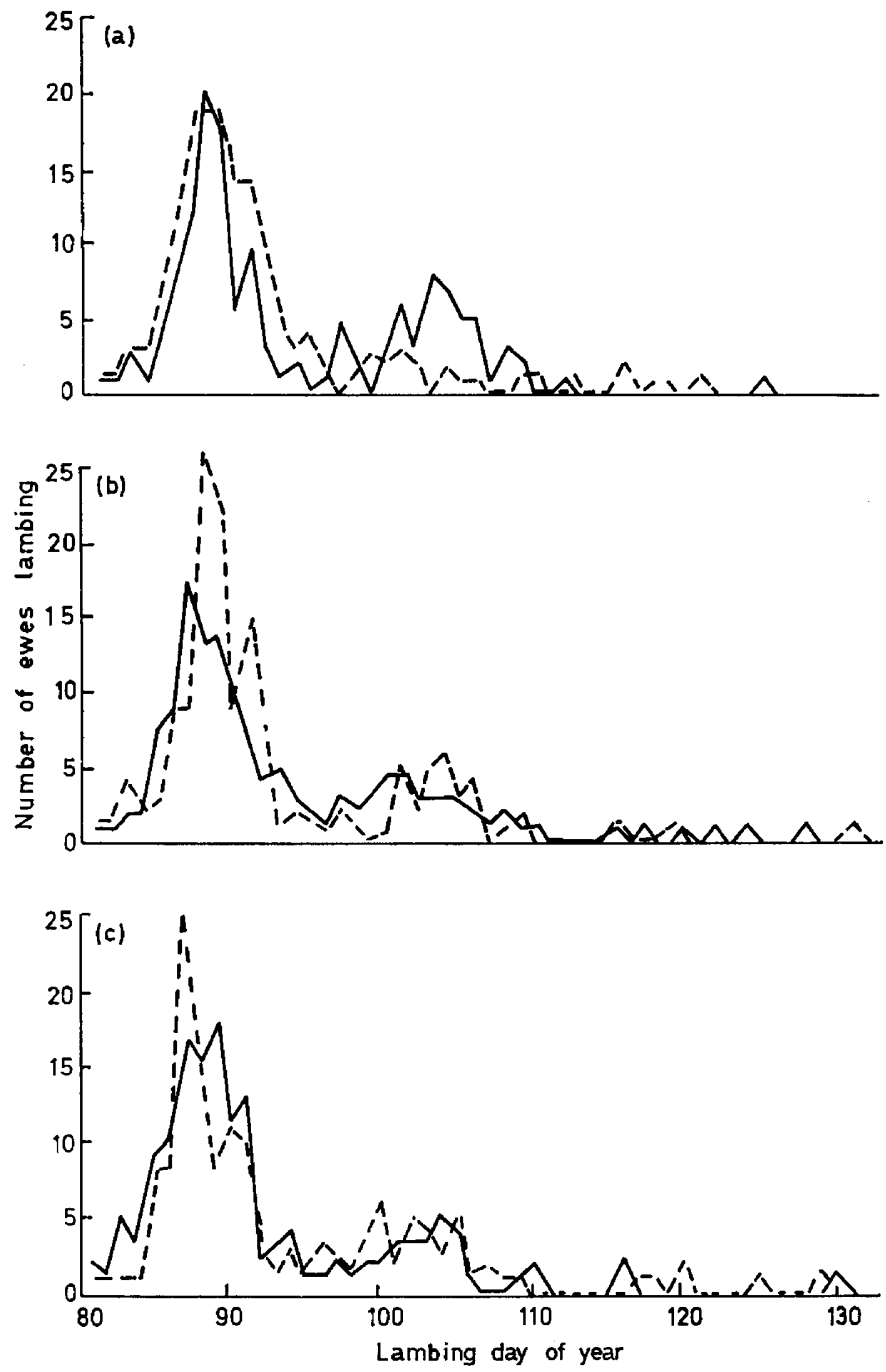

TExT-Fig. 1. Effects of various synchronization treatments using 6-methyl-17-acetoxyprogesterone (MAP) on the distribution of lambing.

(a) $\longrightarrow$, Initial mating at first post-MaP treatment oestrus; - - - . - . - initial mating at second post-MAP treatment oestrus.

(b) $\longrightarrow, 50 \mathrm{mg} \mathrm{MAP} /$ head/day; . . . . . . - , $60 \mathrm{mg} \mathrm{MAP} / \mathrm{head} / \mathrm{day}$.

(c) —-, 12 days MAP treatment; -......, 14 days MAP treatment.

at first, second and third services, and ewes not lambing; (2) Lambing date; and (3) percentage of lambs born of ewes lambing. Ewes lambing to service at the first, second or subsequent heats after exposure to the ram are treated as lambing to the first, second or subsequent service. There was no evidence of 
interactions and the differences between years were small and lacked significance. Therefore, the data were pooled over years and the differences in the main effects were tested by the $\chi^{2}$-test.

The frequency distributions in Text-fig. 1 show the effects on lambing dates of putting rams with the ewes at first or second heats, 50 versus $60 \mathrm{mg} \mathrm{MAP} /$ day and 12 days versus 14 days MAP treatment. The frequency distribution curves show quite clearly those ewes lambing to first, second and third services.

A higher proportion of ewes lambed to first service (Table 1) in a group that were first mated at the second heat $(123 / 162,75.9 \%)$ than in a group that were first mated at the first heat $(89 / 158,56 \cdot 3 \%)$. The second heat was significantly more fertile than the first $(P<0.01)$.

\section{TABLE 1}

EFFECTS OF VARIOUS TREATMENTS ON THE NUMBER OF EWES LAMBING TO FIRST, SECOND AND SUBSEQUENT SERVICES

\begin{tabular}{|c|c|c|c|c|c|c|c|}
\hline \multirow[b]{2}{*}{ Treatment } & \multicolumn{7}{|c|}{ No. of ewes lambing to each service } \\
\hline & \multicolumn{2}{|c|}{ No. ${ }^{\text {First }} \%$} & \multicolumn{2}{|c|}{ Second } & \multicolumn{2}{|c|}{$\begin{array}{l}\text { Third and later* } \\
\text { No. } \%\end{array}$} & $\begin{array}{c}\text { Total } \\
\text { No. ewes }\end{array}$ \\
\hline $\begin{array}{l}\text { First post-treatment oestrus breed- } \\
\text { ing }\end{array}$ & 89 & $56 \cdot 3$ & 51 & $32 \cdot 3$ & 18 & $11 \cdot 4$ & 158 \\
\hline $\begin{array}{l}\text { Second post-treatment oestrus } \\
\text { breeding }\end{array}$ & 123 & $75 \cdot 9$ & 18 & $11 \cdot 1$ & 21 & $13 \cdot 0$ & 162 \\
\hline $\begin{array}{l}50 \mathrm{mg} \mathrm{MAP} \\
60 \mathrm{mg} \mathrm{MAP}\end{array}$ & $\begin{array}{r}98 \\
114\end{array}$ & $\begin{array}{l}59 \cdot 8 \\
73 \cdot 1\end{array}$ & $\begin{array}{l}36 \\
33\end{array}$ & $\begin{array}{l}22 \cdot 2 \\
21 \cdot 2\end{array}$ & $\begin{array}{r}30 \\
9\end{array}$ & $\begin{array}{r}18 \cdot 3 \\
5 \cdot 8\end{array}$ & $\begin{array}{l}164 \\
156\end{array}$ \\
\hline $\begin{array}{l}12 \text { days on MAP } \\
14 \text { days on MAP }\end{array}$ & $\begin{array}{r}114 \\
98\end{array}$ & $\begin{array}{l}70 \cdot 8 \\
61 \cdot 6\end{array}$ & $\begin{array}{l}30 \\
39\end{array}$ & $\begin{array}{l}18 \cdot 6 \\
24 \cdot 5\end{array}$ & $\begin{array}{l}17 \\
22\end{array}$ & $\begin{array}{l}10 \cdot 6 \\
13 \cdot 8\end{array}$ & $\begin{array}{l}161 \\
159\end{array}$ \\
\hline
\end{tabular}

* Includes ewes not lambing.

The lambing percentage to second service was higher among ewes mated first at the first heat $(51 / 158$ ewes, $32.3 \%)$ than among ewes mated first at the second heat $(18 / 162$ ewes, $11 \cdot 1 \%$ ). Ewes lambing to the second service include some which failed to conceive to the first either because of factors associated with the MAP treatment used to synchronize oestrus or for other reasons which should have been equal for both groups. This finding indicates that a somewhat lower level of fertility exists immediately after synchronization and that fertility returns to normal thereafter. There was little difference in the number of ewes lambing for the two treatments when all opportunities for conception were counted.

Dosage rate had a significant effect on the distribution of lambing $(P<0.01)$. An important part of this difference appears to be due to a higher proportion of late lambing and dry ewes in the $50 \mathrm{mg}$ group as compared to the $60 \mathrm{mg}$ group (thirty ewes versus nine ewes). The percentages of ewes lambing to the first service after $50 \mathrm{mg}$ or $60 \mathrm{mg}$ MAP were not significantly different.

Although a higher proportion of ewes lambed to matings at the first service following 12 days of treatment than following 14 days of treatment $(70.8 \%$ versus $61.6 \%$ ) the differences were not significant. 
The percentage of lambs born of ewes lambing were: first versus second heat, $160 \%$ and $151 \%$; 50 versus $60 \mathrm{mg} \mathrm{MAP,}, 157 \%$ and $153 \% ; 12$ versus 14 days MAP, $156 \%$ and $153 \%$, respectively. None of these differences was significant.

\section{The MAP was supplied by the Upjohn Company, Kalamazoo, Michigan.}

\section{REFERENCES}

Brunner, M. A., Hansel, W. \& Hogue, D. E. (1964) Use of 6-methyl-17-acetoxyprogesterone and pregnant mare serum to induce and synchronize estrus in ewes. F. Anim. Sci. 23, 32.

Davis, H. L. (1960) Reduced fertility associated with the use of multiple injections of progesterone followed by pregnant mare serum. Aust. vet. F. 36, 1.

Foote, W. C. \& WATTE, A. B. (1965) Some effects of progesterone on estrous behavior and fertility in the ewe. F. Anim. Sci. 24, 151.

Hogue, D. E., Hansel, W. \& Bratton, R. W. (1962) Fertility of ewes bred naturally and artificially after estrous cycle synchronization with an oral progestational agent. F. Anim. Sci. 21, 625. 